Truskolaski T., Kształtowanie warunków wspótpracy w oparciu o model triple helix na przykładzie metropolii biatostockiej, „Ekonomia i Prawo”, Polszakiewicz B., Boehlke J. (red.), Tom XII, nr 1/2013, ss. 21-34 DOI: http://dx.doi.org/10.12775/EiP.2013.002

\title{
KSZTAŁTOWANIE WARUNKÓW WSPÓŁPRACY W OPARCIU O MODEL TRIPLE HELIX NA PRZYKŁADZIE METROPOLII BIAŁOSTOCKIEJ
}

\section{STRESZCZENIE}

Innowacyjność obszarów miejskich stanowi kluczowy problem na drodze do rozwoju społeczności lokalnych, ich prosperity. Coraz częściej do wprowadzania lokalnych reform wykorzystywana jest zasada triple helix. Poprawne funkcjonowanie miast wymaga współpracy wszystkich beneficjentów. Stąd tak ważna jest właściwa koordynacja działań i świadomość ról wykonywanych w tym procesie. Samorządy mają największą możliwość skoordynowania działań i polityk uwzględniających zasoby i potrzeby wszystkich trzech grup: biznesu, administracji i nauki. Wykorzystanie uprawnień pozwala na prowadzenie polityk długookresowych przyczyniających się do wzrostu innowacyjności regionu i poprawy sytuacji gospodarczej. Artykuł przedstawia praktyczne wykorzystanie zasady triple helix na przykładzie Białegostoku - metropolii, która rozwija się opierając się na osiągnięciach nauki, wspierając przedsiębiorczość, dążąc do uzyskania korzyści dla wszystkich zainteresowanych grup.

Słowa kluczowe: innowacyjność obszarów miejskich, rozwój miast, przedsiębiorczość, samorząd terytorialny, gospodarka oparta na wiedzy

Klasyfikacja JEL: O, O4, O43, R, R1, R11

* Tadeusz Truskolaski, Uniwersytet w Białymstoku, Wydział Ekonomii i Zarządzania, Zakład Polityki Regionalnej i Zarządzania Projektami, ul. Warszawska 6, 15-062 Białystok, e-mail: tadeusz.truskolaski@post.pl. 


\title{
CREATION OF COOPERATION CONDITIONS BASED ON TRIPLE HELIX MODEL: THE CASE STUDY OF BIAŁYSTOK METROPOLIS
}

\author{
SUMMARY
}

Urban innovation is a key problem on the way to the development of local communities and their prosperity. The principle of triple helix is used to implement local reforms. The proper functioning of cities requires the cooperation of all beneficiaries. Hence, proper coordination and the awareness of the roles performed in the process, is of vital importance. Local governments have the greatest opportunity to coordinate activities and policies which take into account the needs and resources of all three groups: business, administration and science. The use of power allows for long-term policies that contribute to the increase in innovation and the improvement of the region's economic situation. This paper presents the practical use of the triple helix principle. It is the case study of Bialystok - the metropolis, whose development is based on the achievements of science and which supports entrepreneurship, for the benefit of all stakeholders.

Keywords: urban innovation, urban development, entrepreneurship, local governments, knowledge-based economy

JEL Classification: O, O4, O43, R, R1, R11

\section{WSTĘP}

W czasach globalizacji, konkurencyjność obszarów miejskich i regionów zależy od wykorzystania posiadanych zasobów wiedzy, umiejętności oraz kreatywności. Z prowadzonych badań wynika, że innowacyjność w coraz większym stopniu jest uzależniona od sprawnego przepływu informacji i wiedzy, a stopień jej rozwoju i wykorzystania wpływa na podnoszenie konkurencyjności miast i regionów.

Jednym ze współczesnych kierunków rozwoju innowacyjności w skali lokalnej jest efektywne wykorzystanie zasady triple helix, czyli współpracy pomiędzy nauką, biznesem i władzami publicznymi. W ujęciu całościowym ten model współpracy przejawia się jako zbiór specyficznych, elastycznych i uniwersalnych powiązań przedsiębiorstw, instytucji naukowo-badawczych, organizacji pozarządowych, inicjatyw obywatelskich i sektora publicznego.

Celem opracowania jest wskazanie wzajemnych relacji pomiędzy poszczególnymi aktorami procesu współpracy, w tym szczególnej roli władz publicznych służącej kształtowaniu klimatu i tworzeniu warunków sprzyjających 
powstawaniu i organizacji innowacyjnych procesów, a zarazem budowy infrastruktury instytucjonalnej ułatwiającej ich rozwój. Dlatego tworzone są mechanizmy do ciągłego wykorzystywania i komercjalizacji wiedzy. Dotyczy to również wspierania rozwoju szeroko pojętego kapitału ludzkiego, podnoszenia jakości i poziomu kształcenia kadr w poszczególnych przedsiębiorstwach i całych branżach.

\section{PROBLEMY ROZWOJU INNOWACYJNOŚCI W REGIONIE I PRÓBY ICH ROZWIĄZYWANIA}

Współczesna teoria biznesu uznaje wiedzę jako najważniejszy zasób przedsiębiorstwa. Dla regionu, w którym rozwój przedsiębiorczości ma odgrywać istotną rolę, edukacja powinna być punktem wyjściowym do dalszych działań. Regionalna promocja przedsiębiorczego ducha i kompetencji w procesie edukacji jest podstawą do propagowania przedsiębiorczego podejścia w kształceniu jednostek, struktur społecznych i organizacji. Regiony mając do dyspozycji fundusze strukturalne UE i inne środki finansowe, powinny odpowiednio planować i kształtować proces budowy „regionów wiedzy i innowacji” lub „miast wysokich technologii”. W tych warunkach wykształciły się tzw. podmioty pomostowe - instytucje wsparcia partnerstwa społeczno-ekonomicznego na rzecz budowy gospodarki opartej na wiedzy, jakimi są ośrodki innowacji. Wnoszą one do partnerstwa trzech sektorów takie elementy, jak: inicjatywę, pomysły, kontakty, koordynację i znajomość potrzeb środowiska.

W czasach, gdy społeczeństwo wkracza w nową erę gospodarki opartej na wiedzy, informacja nabiera kluczowego znaczenia. Jej poziom i dostępność należy uznać za jeden z najważniejszych czynników decydujących o jakości procesów rozwoju społeczno-gospodarczego. Sprawne zarządzanie informacją w makrosystemie: gospodarka-społeczeństwo - -środowisko jest podstawą jego skutecznego funkcjonowania oraz budowy zrównoważonego i trwałego rozwoju w warunkach gospodarki opartej na wiedzy ${ }^{1}$.

Jedną $\mathrm{z}$ rozwiniętych i zintegrowanych form tworzenia środowiska innowacyjnego są klastry, czyli „geograficzne skupiska wzajemnie powiązanych firm, wyspecjalizowanych dostawców, jednostek świadczących usługi, firm działających w pokrewnych sektorach i związanych $z$ nimi instytucji (uniwersytetów, jednostek normalizacyjnych i stowarzyszeń branżowych) w poszcze-

1 B. Poskrobko (red.), Gospodarka oparta na wiedzy, Materiaty do studiowania, Wyższa Szkoła Ekonomiczna w Białymstoku, Białystok 2011, s. 157-168. 
gólnych dziedzinach, konkurujących między sobą, ale także współpracujących”2. Badania przeprowadzone $\mathrm{w}$ ostatnim dziesięcioleciu wykazują, iż inicjatywy klastrowe we współczesnej gospodarce są nie tylko skutecznym sposobem podnoszenia konkurencyjności przedsiębiorstw - uczestników klastra, ale także kreują innowacje oraz generują szereg pozytywnych efektów zewnętrznych dla regionu, na którym są zlokalizowane ${ }^{3}$.

W obecnych uwarunkowaniach istnieje jednak szereg barier uniemożliwiających swobodne kształtowanie współpracy w triadzie: biznes-nauka-administracja. Do nich należy np. niedostateczne dostrzeganie przez sektor biznesu potrzeby współpracy ze sferą $B+R$, brak wystarczających informacji o potencjalnych partnerach ze sfery $B+R$ i ich specjalizacji. Przeszkodą są zawiłe procedury administracyjne zwłaszcza te dotyczące nawiązywania i prowadzenia współpracy, a także brak dostatecznej ilości środków publicznych udostępnionych na finansowanie badań sfery $\mathrm{B}+\mathrm{R}$, którą postrzega się jako obarczoną dużym ryzykiem.

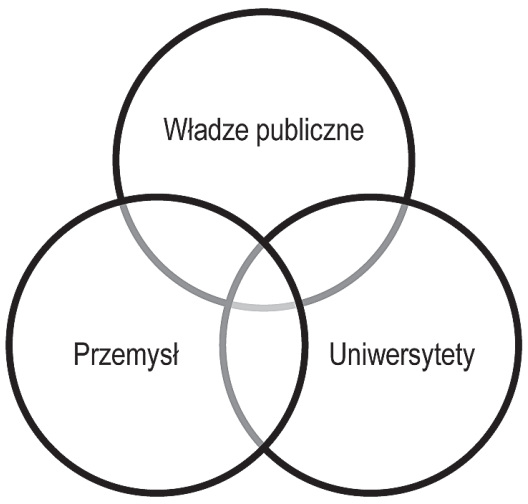

Rysunek 1. Model współpracy triple helix

Źródło: H. Etzkowitz, The Triple Helix of University - Industry - Government. Implications for Policy and Evaluation, "Working Paper", 2002, no. 11, Institutet för studier av utbildning och forskning Drottning Kristinas väg 33D, Stockholm, s. 4.

Kolejnym elementem mogącym przyczynić się do podnoszenia poziomu innowacyjności na szczeblu regionalnym i lokalnym jest model triple helix.

${ }^{2}$ Benchmarking klastrów w Polsce - 2010. Raport z badania, Warszawa 2010, s. 9.

3 J. Adamska, J. Kotra, Kreowanie środowiska innowacyjnego w parkach technologicznych, PARP, Poznań-Gliwice 2011 s. 43-45. 
Triple helix jest spiralnym modelem innowacji, który prezentuje różnorodne, wzajemne relacje na różnych etapach procesu kapitalizacji wiedzy ${ }^{4}$. Model triple helix wspiera i promuje procesy innowacyjneopierając się na współpracy pomiędzy uczelniami, przemysłem i władzami publicznymi.

Model ten opiera się na trzech podstawowych założeniach:

1. Znacząca rola uczelni wyższych w procesie tworzenia innowacji na równi z przemysłem i rządem w społeczeństwie opartym na wiedzy.

2. Dążenie do współpracy pomiędzy trzema głównymi sferami instytucjonalnymi dla których polityka innowacji coraz częściej jest wynikiem ich interakcji, a nie wytycznych ze strony rządu.

3. Każda instytucja, oprócz pełnienia swoich tradycyjnych funkcji, przejmuje w pewnym zakresie w rolę dwóch pozostałych. Na przykład uniwersytet może przejmować rolę rządu w zakresie inicjowania projektów rozwojowych lub rolę przemysłu w tworzeniu firm. Uniwersytety tradycyjnie są źródłem zasobów ludzkich i wiedzy, a we współczesnym społeczeństwie stają się istotnymi podmiotami wpływającymi na rozwój społeczno-ekonomiczny. Nadal wykonują swoje tradycyjne zadania, ale w coraz większym stopniu biorą na siebie zadania $\mathrm{z}$ zakresu postępu innowacji i rozwoju ${ }^{5}$. W dalszej części opracowania przedstawione zostaną przykłady aktywności organu samorządowego, Miasta Białegostoku, które mam zaszczyt reprezentować, gdzie Miasto jest inicjatorem i akceleratorem działań w wielu obszarach współpracy, starając się rozwiązywać wyżej wymienione problemy.

\section{BIAŁYSTOK - GOSPODARCZY PROFIL MIASTA}

Białystok jest największym miastem (ok. 300 tys. mieszkańców) północno-wschodniej Polski i stolicą województwa Podlaskiego. Miasto było znaczącym w skali kraju ośrodkiem przemysłu włókienniczego. Rozwinął się też tu przemysł spożywczy, elektromaszynowy (elektroniczny, maszynowy, metalowy) oraz drzewny i materiałów budowlanych. Obecnie wiodącymi branżami w gospodarce Białegostoku są: przetwórstwo rolno-spożywcze, przemysł elektrotechniczny, budownictwo ogólne i specjalistyczne. Na koniec 2011 roku zarejestro-

${ }^{4} \mathrm{H}$. Etzkowitz, The Triple Helix of University - Industry - Government. Implications for Policy and Evaluation, „Working Paper” 2002, no. 11, Institutet för studier av utbildning och forskning Drottning Kristinas väg 33D, Stockholm, s. 2.

${ }^{5}$ J. Dzisah, H. Etzkowitz, Triple helix circulation:the heart of innovation and development, „International Journal of Technology Management and Sustainable Development”, 2008, vol. 7, no. 2, s. 103. 
wanych było (zgodnie z REGON) ponad 31,3 tys. podmiotów gospodarczych prowadzących działalność gospodarczą, z tego ok. 24,3 tys. $(77,6 \%)$ stanowią osoby fizyczne prowadzące działalność gospodarczą oraz ok. 2,4 tys. $(7,6 \%)$ to spółki handlowe, w tym 304 z udziałem kapitału zagranicznego.

Profil ekonomiczny miasta ulega permanentnym zmianom. W okresie ostatnich dwóch latach zostało zarejestrowanych w systemie REGON ponad 1,3 tys. nowych podmiotów gospodarczych, z tego ok. 760 podmiotów osób fizycznych prowadzących działalność gospodarczą oraz 261 nowych spółek handlowych, w tym $45 \mathrm{z}$ udziałem kapitału zagranicznego.

Znaczący wpływ na rozwój gospodarczy miasta ma potencjał akademicki. Obecnie w Białymstoku funkcjonuje 18 uczelni wyższych, na których łącznie z filiami i punktami zamiejscowymi szkół wyższych, w tym z Filią Uniwersytetu w Białymstoku w Wilnie oraz cudzoziemcami studiuje ok. 46 tys. studentów. Najstarszą uczelnią wyższą Białegostoku jest Uniwersytet Medyczny. Natomiast Politechnika Białostocka jest największą uczelnią techniczną w północno-wschodniej Polsce, a Uniwersytet w Białymstoku - największą uczelnią kształcącą m.in. humanistów, prawników, ekonomistów oraz przedstawicieli nauk ścisłych jak chemia, fizyka i matematyka. Eącznie na białostockich uczelniach wyższych zatrudnionych jest ponad 2,7 tys. nauczycieli akademickich, w tym ponad 2,2 tys. osób to kadra naukowo-dydaktyczna, a mury białostockich uczelni opuszcza średnio ok. 12,8 tys. absolwentów, z tego ponad 3,1 tys. (24,1\%) stanowią absolwenci szkół technicznych. $Z$ tych względów branża IT - informatyczna w Białymstoku zyskuje szczególne znaczenie w rozwijaniu innowacyjnej gospodarki opartej na wiedzy.

\section{WSPÓŁPRACA W METROPOLII BIAŁOSTOCKIEJ}

Do podstawowych funkcji metropolitalnych jakie pełni miasto Białystok $\mathrm{w}$ regionie należy zaliczyć:

- administracyjną - jako stolica województwa Podlaskiego, powiatu grodzkiego i ziemskiego, siedziba administracji rządowej i samorządowej oraz placówek dyplomatycznych i organizacji międzynarodowych lub ich filii;

- kulturową - pełni rolę stolicy kulturowej regionu Podlasia;

- edukacyjno-naukową - pełni rolę centrum edukacyjnego regionu;

- gospodarczo-finansową - związaną z bazą ekonomiczną, a także z rozwiniętym sektorem bankowym oraz instytucjami otoczenia biznesu;

- komunikacyjną i logistyczną - miasto dobrze skomunikowane, posiadające połączenia kolejowe i drogowe, zarówno w komunikacji lokalnej, regionalnej jak i międzynarodowej. 
Współpraca w formule triple helix traktowana jest jako priorytet i podstawowy element kształtowania postaw społeczeństwa obywatelskiego, który prowadzi do lepszego, bardziej świadomego i odpowiadającego potrzebom społecznym planowania i podejmowania szerokich, integrujących działań prospołecznych i prorozwojowych. Potrzebę nawiązywania i kształtowania takiej formy współpracy zaakcentowano już w Strategii Rozwoju Białegostoku uchwalonej przez Radę Miejską Białegostoku w 1996 roku6 . Jednym z efektów wskazanych w obowiązującej do 2010 roku Strategii działań, mających na względzie zapewnienie udziału przedstawicieli środowiska gospodarczego oraz przedstawicieli wyższych uczelni w kształtowaniu polityki gospodarczej Białegostoku było powołanie w 2003 roku Rady Gospodarczej przy Prezydencie Miasta Białegostoku, która od 2007 roku funkcjonowała pod nazwą Rada Przedsiębiorczości przy Prezydencie Miasta Białegostoku. Od 2011 roku zmieniono nazwę Rady na Radę Ekspertów ds. Gospodarczych przy Prezydencie Miasta Białegostoku. Aktualnie skład Rady liczący 15 członków tworzą przedstawiciele Podlaskiego Forum Gospodarczego - 5 osób, ekspert ds. medycznych, ekspert ds. budownictwa, ekspert ds. strategii rozwoju miasta, ekspert ds. analizy i badania rynku pracy, ekspert ds. nowoczesnych technologii oraz przedstawiciel klastra bieliźniarskiego i Białostockiej Fundacji Kształcenia Kadr ${ }^{7}$.

W obecnych warunkach funkcjonowania gospodarki, w której zachodzą procesy ukierunkowane na tworzenie zasobów i postaw innowacyjnego środowiska, szansy na utrzymanie przewagi konkurencyjnej upatruje się głównie w regionach i ośrodkach metropolitalnych. W regionach następuje ustawiczny rozwój zdolności innowacyjnych i budowa gospodarki opartej na wiedzy. Wymaga to długofalowych i synchronizowanych działań władz samorządu terytorialnego prowadzonych na różnych płaszczyznach ${ }^{8}$. Najbardziej efektywnym sposobem tworzenia innowacyjnej gospodarki jest przyswajanie, przekazywanie i efektywne wykorzystywanie osiągnięć naukowych przez przedsiębiorstwa, organizacje, społeczeństwo i osoby fizyczne, co powinno sprzyjać dynamiczne$\mathrm{mu}$ rozwojowi ekonomiczno-społecznemu'.

Model działania obejmujący współpracę między uczelniami, przedsiębiorstwami i władzami lokalnymi, zakładający istotną rolę uczelni wyższych w regionalnych procesach innowacji, władze lokalne Białegostoku zaliczają do najbardziej aktualnych i kluczowych czynników rozwoju gospodarczego biało-

${ }^{6}$ Strategia Rozwoju Biategostoku, Urząd Miejski w Białymstoku, Białystok 1996, s. 86.

7 Zarządzenie Nr 1530/11 Prezydenta Miasta Białegostoku z dnia 17 listopada 2011 r.

8 B. Poskrobko (red.), op. cit., s. 41-54.

9 B. Powichrowska (red.), Przedsiębiorstwo w warunkach zrównoważonej gospodarki opartej na wiedzy, Wyższa Szkoła Ekonomiczna w Białymstoku, Białystok 2011, s. 40-42. 
stockiej metropolii. Aby sprostać powyższym wyzwaniom, gdy wiodącym wyznacznikiem rozwoju gospodarczego jest stopień innowacyjności (podnoszenie jego poziomu jest obecnie jednym z najważniejszych wyzwań Unii Europejskiej), władze Białegostoku stworzyły „Strategię Rozwoju Miasta Białegostoku na lata 2011-2020 plus" opierając się na zasadach modelu partycypacyjnego przy wykorzystaniu fachowej wiedzy i doświadczenia ekspertów ${ }^{10}$.

Strategia została uchwalona przez Radę Miejską Białegostoku w 2010 roku, w której został wyznaczony cel strategiczny do osiągnięcia w obszarze rozwoju gospodarczego pn. „Długofalowy wzrost gospodarki opartej na wiedzy i w konsekwencji większa liczba jakościowo lepszych miejsc pracy”. Realizacja tego celu będzie wymagała podjęcia działań w partnerstwie triple helix, takiego typu jak:

- rozwój systemu usług wsparcia MSP - realizowane poprzez zapewnienie dostępu na preferencyjnych warunkach do źródeł kapitału, usług doradczych (w tym szczególnie ważnym jest doradztwo w zakresie działalności eksportowej) oraz usług szkoleniowych;

- stworzenie i wdrożenie strategii rozwoju oraz wspieranie konkurencyjności wiodących i najbardziej innowacyjnych sektorów gospodarki miasta poprzez promowanie współpracy, na przykład przez tworzenie klastrów i promowanie dobrowolnej kooperacji przedsiębiorstw, jednostek naukowych, edukacyjnych i innych instytucji celem uzyskania korzyści wynikających $z$ sieciowej współpracy pomiędzy przedsiębiorstwami i otoczeniem naukowo-badawczym;

- wsparcie innowacyjności - zapewnienie odpowiedniej bazy technicznej dla rozwoju sektora wysokich technologii poprzez rozwój infrastruktury innowacyjności;

- współpraca ze szkołami i uczelniami wyższymi oraz instytucjami rynku pracy w kierunku dostosowania działalności edukacyjnej pod kątem potrzeb inwestorów - poprzez zapewnienie dostępności do wykwalifikowanych kadr, uelastycznianiu systemu kształcenia na wyższych uczelniach i instytucjach edukacyjnych poprzez dostosowywanie oferty edukacyjnej do potrzeb inwestorów ${ }^{11}$;

- konieczność tworzenia aktywnej współpracy z wykorzystaniem zasady triple helix podkreślono w Regionalnej Strategii Innowacji Województwa Podlaskiego ${ }^{12}$.

10 Strategia Rozwoju Miasta Biategostoku na lata 2011-2020 plus, Urząd Miejski w Białymstoku, Białystok 2010, s. 9-14.

${ }^{11}$ Ibidem, s. 111-117.

12 Regionalna Strategia Innowacji Województwa Podlaskiego, Wydawnictwo Uniwersytetu w Białymstoku, Białystok, 2004, s. 5. 
Tym samym uchwalona Regionalna Strategia Innowacji Województwa Podlaskiego tworzy fundamenty instytucjonalne pod współpracę sektora MŚP $\mathrm{z}$ jednostkami naukowymi i badawczymi oraz władzami samorządowymi. Ma także wpływ na utworzenie sprawnych kanałów informacyjnych o dostępnych nowoczesnych technologiach, możliwościach ich pozyskania i wdrożenia w warunkach lokalnego biznesu.

\section{INICJATYWY Z BIZNESEM I DLA BIZNESU}

Przykładem współpracy przedsiębiorstw, instytucji B+R i sektora publicznego jest przygotowanie i realizacja projektu pn. Białostocki Park Naukowo -Technologiczny, którego beneficjentem jest Miasto Białystok, (projekt realizowany w latach 2008-2012, współfinansowany ze środków Europejskiego Funduszu Rozwoju Regionalnego w ramach Programu Operacyjnego Rozwój Polski Wschodniej na lata 2007-2013). Wartość projektu to ok. 167,4 mln z1, $\mathrm{z}$ czego dofinansowanie $\mathrm{z}$ UE wynosi ok. $119 \mathrm{mln} \mathrm{zf}^{13}$.

Potrzeba utworzenia Parku wynikała z następujących przesłanek:

- wysokie skupienie przedsiębiorstw w Białymstoku (ok. 34,1\% potencjału działalności gospodarczej i ok. 39,6\% pracujących województwa podlaskiego);

- rozwinięta sfera naukowo-badawcza, w tym: Uniwersytetu Medycznego z szeroką ofertą edukacyjną zgodną z potrzebą rozwijających się dziedzin służby zdrowia oraz rynku pracy, Politechniki Białostockiej z instytutami specjalizującymi się w badaniach nad infrastrukturą drogowo-mostową, budowlaną, ochroną środowiska oraz Uniwersytetu w Białymstoku dysponującego instytutami doświadczalnymi w dziedzinie fizyki, informatyki, chemii organicznej i nieorganicznej oraz ochrony środowiska i biologii;

- ograniczone zdolności finansowe podlaskich jednostek naukowo-badawczych w rozwijaniu nowych technologii, badań oraz w odtwarzaniu środków trwałych czy zakupie nowych powoduje, iż postęp w pracach jest nieadekwatny do zmieniającej się gospodarki oraz jej zapotrzebowania na innowacje;

- rozdrobnienie licznych organizacji wspierających przedsiębiorczość i innowacyjność - występuje powolny i niepełny przepływ informacji pomiędzy nimi, niektóre zadania organizacji są dublowane;

13 Dane na podstawie Bazy Projektów Unijnych, prowadzonej przez Biuro Funduszy Europejskich Urzędu Miejskiego w Białymstoku, aktualizacja 03.07.2012 r. 
— trudności przedsiębiorców w dotarciu do właściwej organizacji oraz niski stopień innowacyjności podlaskich przedsiębiorstw.

Park w swojej strukturze organizacyjnej funkcjonuje jako wyodrębniona jednostka organizacyjna Urzędu Miejskiego. Ponadto powołana została przez Prezydenta Miasta Rada Programowa ${ }^{14}$, pełniąca funkcję organu o charakterze doradczym dla Parku. Rada Programowa składa się z przedstawicieli wiodących środowisk naukowych Białegostoku - oraz specjalistów branż preferowanych przez Park i prawnikóPoprawie współpracy między różnymi środowiskami i instytucjami może służyć inicjowanie i zawieranie przez samorządy partnerstw, ukierunkowanych na rozwój nauki i przedsiębiorczości. Ta współpraca może przybierać rozmaite formy prawne: fundacje, rady, izby, agencje, stowarzyszenia, spółki czy konsorcja naukowo-przemysłowe. W tym aspekcie współpracy Miasto Białystok udziela się w organizacjach wspierających rozwój przedsiębiorczości, co w konsekwencji stymuluje bezpośrednio lokalny, a pośrednio regionalny, rozwój gospodarczy.

Miasto dba o wychowanie oraz kształcenie młodego pokolenia - kluczowego czynnika rozwoju. Nawiązano współpracę na rzecz edukacji z organizacjami branżowymi przedsiębiorców - Podlaskim Forum Gospodarczym, Izbą Rzemieślniczą i Przedsiębiorczości oraz wiodącymi białostockimi uczelniami wyższymi. Celem zawartych w 2007 roku porozumień jest współuczestnictwo partnerów wspólnie $\mathrm{z}$ władzami miasta w: identyfikowaniu ważnych problemów edukacyjnych i wypracowywanie sposobów ich rozwiązywania, wspieranie szkół $\mathrm{w}$ realizacji programów wychowawczo-profilaktycznych oraz uczestnictwa młodzieży w prowadzonych praktykach, popularyzacji kształcenia ustawicznego wśród pracodawców, inspirowanie pracodawców do aktywnego włączania się w proces kształcenia w zawodzie, w szczególności kształcenia praktycznego.

Kolejną wykorzystywaną formą współpracy w modelu tryple helix może być inicjowanie i rozwijanie innowacyjnych regionalnych (subregionalnych) klastrów badawczych łączących przede wszystkim przedsiębiorstwa, ale także uniwersytety, ośrodki badawcze i władze samorządowe. Istotą takiego stanu rzeczy jest dbałość o właściwy rozwój potencjału naukowego poprzez wspieranie rozwoju wyspecjalizowanych centrów zaawansowanych technologii (centrów doskonałości) dysponujących wysokim potencjałem naukowym nakierowanych na współpracę z przemysłem. Tego typu wspólne działania mogą się przyczynić do utworzenia zaplecza badawczo-rozwojowego pracującego na rzecz przedsiębiorców w kierunku rozwijania strategicznych programów badawczych.

${ }^{14}$ Uchwała Nr XI/78/11 Rady Miejskiej Białegostoku z dnia 18.04.2011 r. 
W tym nurcie została zainicjowana idea utworzenia i rozwoju białostockiej „dzielnicy wiedzy” zlokalizowanej w południowej części miasta i obejmującej:

— powstałą w 2008 r. Podstrefą Białystok Suwalskiej Specjalnej Strefie Ekonomicznej;

- powstający Białostocki Park Naukowo-Technologiczny, który zostanie oddany do użytku w bieżącym okresie programowania;

- powstający Kampus Uniwersytecki, którego oddanie do użytku przewidywane jest w 2015 r.

Przewiduje się, że w tym modelu powiązań sieciowych szczególna rola przypadać będzie dla Białostockiego Parku Naukowo-Technologicznego, który powinien być ściśle powiązany ze środowiskiem przemysłowym (małe i średnie przedsiębiorstwa oraz duże firmy) - szczególnie te zlokalizowane $\mathrm{w}$ bezpośrednim położeniu Parku lub w Podstrefie Specjalnej Strefy Ekonomicznej, przy czym jego aktywność winna być skoncentrowana na innowacyjnych technologiach - tworzonychopierając się na badaniach własnych bądź transferowanych z innych ośrodków wiedzy, takich jak np. Kampus Uniwersytecki.

\section{ZAKOŃCZENIE}

Należy podkreślić, że uczelnie i jednostki $\mathrm{B}+\mathrm{R}$, samorządy oraz przedsiębiorcy, głównie ci pochodzący z sektora MŚP, odgrywają znaczącą rolę w rozwoju Białegostoku i regionu. Zarówno badania, jak i doświadczenia, teoria i praktyka wskazują, że najbardziej efektywną drogą do osiągnięcia zrównoważonego rozwoju jest współpraca tych trzech elementów. Dla rozwoju gospodarczego Białegostoku niezbędne są przedsiębiorstwa oparte na wiedzy, konkurencyjne zarówno w narodowym, jak i międzynarodowym wymiarze. Konieczne jest wspieranie przedsiębiorstw z nowatorskimi pomysłami i umiejętnością adaptacji do zmieniających się warunków rynkowych. W Białymstoku pracuje się nad tym, aby powstały nowe możliwości sprzyjające rozwojowi innowacyjnych podmiotów. W przekonaniu władz Białegostoku nowoczesne, innowacyjne i konkurencyjne przedsiębiorstwa będą głównym motorem i akceleratorem rozwoju gospodarczego metropolii białostockiej.

Efektywność przepływu oraz zdolność tworzenia nowej wiedzy zależy w dużym stopniu od tego, w jaki sposób i na ile zaangażowani uczestnicy danego procesu czy podejmowanego wspólnego przedsięwzięcia stworzą sieci wzajemnych i trwałych relacji oraz skutecznego powiązania wiedzy z praktyką.

Należy jednak pamiętać, że punktem wyjścia do tworzenia przedsiębiorczych regionów jest rozwój systemów edukacji łączących w sobie nauczanie 
z badaniami i kulturą przedsiębiorczości. System edukacji winien być lustrzanym odbiciem wartości dominujących w regionie i całym społeczeństwie. Aby wspierać przedsiębiorczość na szeroką skalę niezbędne jest wprowadzenie rozwiązań systemowych $\mathrm{w}$ procesach nauczania ukierunkowanych na edukację przedsiębiorczości i promocji takiego podejścia w metodach kształcenia stosowanych w uczelniach wyższych, jednostkach naukowo-badawczych oraz organizacjach edukacyjnych. Tym metodom kształcenia przedsiębiorczości powinny towarzyszyć programy wspierające kreatywność, inicjatywę oraz krytyczne myślenie i budowanie interakcji.

Reasumując nie ulega wątpliwości, że wiodącym czynnikiem rozwoju gospodarczego jest stopień innowacyjności gospodarki, a głównym zadaniem i misją władz publicznych jest nieustanne budowanie procesu rozwoju zdolności innowacyjnych, w którym:

- instytucje naukowe i naukowo-badawcze dostarczają odpowiednio przygotowany kapitał ludzki (wykwalifikowane kadry, kreatywne środowisko) oraz wiedzę i nowe technologie, a oczekują ze strony partnerów finansowania wyników badań, ich sprzedaży w formie zleceń na usługi i ekspertyzy a także zatrudniania absolwentów;

- biznes wnosi wdrożenie inwestycji i zdolność do podjęcia ryzyka, zdobycie nowych rynków zbytu i/lub kanałów dystrybucji, a oczekuje wykwalifikowanych zasobów pracy, pojawienia się nowych produktów i technologii, poprawy infrastruktury technicznej i około biznesowej;

- administracja zapewnia koordynowanie działań prorozwojowych poprzez programy wsparcia i zabezpieczenie finansowania działań (udzielanie zamówień publicznych), a oczekuje na dynamizację procesów rozwojowych, wzrost wpływów podatkowych, tworzenie nowych miejsc pracy.

Zgodnie $\mathrm{z}$ powyższym, zintegrowane wysiłki i współdziałanie partnerów $\mathrm{z}$ trzech sfer, tj. biznesu, nauki i administracji będą sprzyjać kreowaniu postaw innowacyjnych zarówno w środowisku naukowym jak i biznesowym, co wpłynie na rozwój potencjału gospodarczego miast i regionów, a zarazem na poprawę ich konkurencyjności i wizerunku.

\section{BIBLIOGRAFIA}

Adamska J., Kotra J., Kreowanie środowiska innowacyjnego w parkach technologicznych, PARP, Poznań-Gliwice 2011.

Benchmarking klastrów w Polsce - 2010, Raport z badania, Warszawa 2010.

Dzisah J., Etzkowitz H., Triple helix circulation:the heart of innovation and development, „International Journal of Technology Management and Sustainable Development”, 2008, Vol. 7, no. 2; http://dx.doi.org/10.1386/ijtm.7.2.101_1. 
Etzkowitz H., The Triple Helix of University - Industry - Government. Implications for Policy and Evaluation, „Working Paper”, 2002, no. 11, Institutet för studier av utbildning och forskning Drottning Kristinas väg 33D, Stockholm.

Nauka i gospodarka 2009/1, Zastosowanie gospodarcze wyników badań i prac badawczych $w$ dziedzinie nauk ekonomicznych, Uniwersytet Ekonomiczny w Krakowie, Kraków 2009.

Nowak M., Mażewska M., Mazurkiewicz S., Wspótpraca ośrodków innowacji z administracja publiczna, PARP, Łódź-Gdańsk-Kielce 2011.

Poskrobko B. (red.), Gospodarka oparta na wiedzy. Materiaty do studiowania, Wyższa Szkoła Ekonomiczna w Białymstoku, Białystok 2011.

Powichrowska B. (red.), Przedsiębiorstwo w warunkach zrównoważonej gospodarki opartej na wiedzy, Wyższa Szkoła Ekonomiczna w Białymstoku, Białystok 2011.

Regionalna Strategia Innowacji Województwa Podlaskiego, Wydawnictwo Uniwersytetu w Białymstoku, Białystok 2004.

Strategia Rozwoju Biategostoku, Urząd Miejski w Białymstoku, Białystok 1996.

Strategia Rozwoju Miasta Biategostoku na lata 2011-2020 plus, Urząd Miejski w Białymstoku, Białystok 2010. 
